\title{
Ultrastructure of Odontella rostrata (Hustedt) Simonsen, a New Record for the South Atlantic Ocean
}

\author{
E. A. Sar
}

División Ficología, Facultad de Ciencias Naturales y Museo, Paseo del Bosque s/n, 1900 La Plata, Argentina

(Accepted 26 December 1988)

\begin{abstract}
Odontella rostrata (Hustedt) Simonsen from the coastal waters of the Río Negro, Argentina, was studied using both light and scanning electron microscopy and it represents a new record for the South Atlantic Ocean.
\end{abstract}

\section{Introduction}

According to Ross and Sims (1971) and Hoban (1983) the biddulphioid species with poroid valves and ocellate elevations should be placed in the genus Odontella while the biddulphioid species with poroid valve and pseudocellate elevations should be placed in the genus Biddulphia.

In this paper the fine structure of the valve of Odontella rostrata (Hustedt) Simonsen was examined with the aim of determining whether its location within this genus is correct according to the criterion described above.

\section{Material and Methods}

The material studied was collected in $20 \mu \mathrm{m}$ mesh plankton nets from San Antonio Bay and San Matías Gulf, Río Negro, Argentina. The samples were preserved in buffered formalin, cleaned of organic matter using the method of Hasle and Syvertsen (1980), mounted in Hyrax for study with the light microscope and in water on glass plugs for observation in the scanning electron microscope. The material has been incorporated in the collection of the Division Ficología, Facultad de Ciencias Naturales y Museo, Universidad Nacional de La Plata as 'Diatom from San Antonio Oeste'.
The observations were carried out with a Wild M20 phase contrast microscope and Jeol J.S.M. 35 CF scanning electron microscope.

The terminology used is that suggested by Ross et al. (1978).

\section{Results}

Odontella rostrata (Hustedt) Simonsen (Figs 1-7) Simonsen, 1987: 250-251, pl 272, figs 1-11. Biddulphia rostrata Hustedt (1939): 591, figs 5-7.

The cells usually occur singly and have convex valves with elevated central areas (Figs 1, 4-6). The valve mantle is turned towards the margin of the valve (Fig. 2). Two elevations, each with a limited perforated plate (ocellus) occur on each valve (Fig. 7). Radial rows of poroid areolae with domed cribum-like vela, with a central granule, ornament the valve surface. From many to just a few siliceous radial ribs are located between the border of the elevated central area and the mantle (Figs 4-6). Twinned pores and spines are relatively well developed and are scattered over the valve (Fig. 7). There are one or two labiate processes located next to the border of the central area and opposite to the elevations. These are sessile 

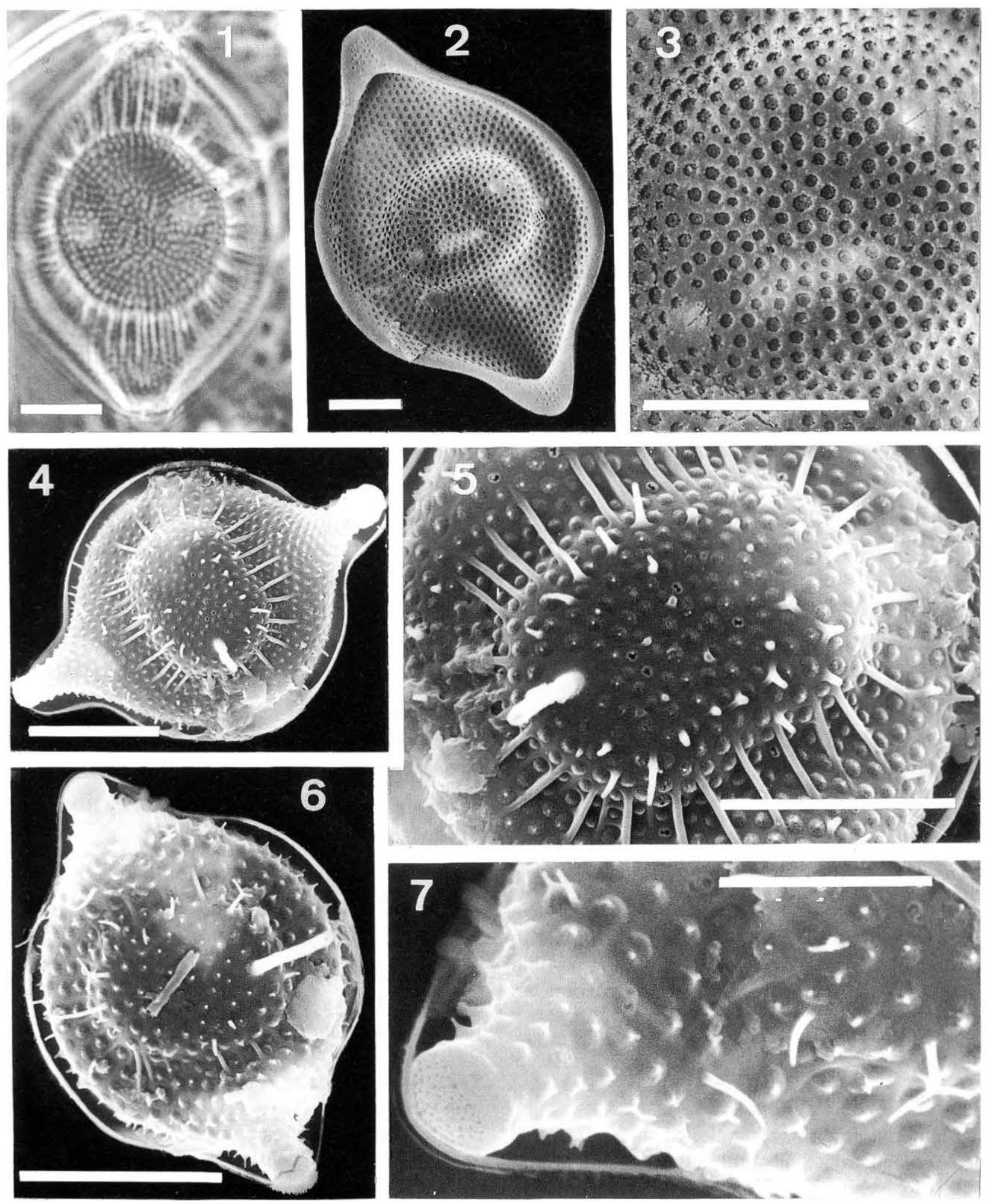

Figs 1-7. Odontella rostrata. Fig. 1. light microscopy, valve view, Hyrax. Figs 2-7. scanning electron microscopy. Figs $2-3$. inside view of valves, detail of labiate processes. Figs 4-7. valves, outside view. Fig. 5. detail of central area with labiate process, spines and siliceous radial ribs. Fig. 7. detail of ocellus and twinned pores.

Scale bar: Figs $1-6,5 \mu \mathrm{m}$; Fig. 7, $2 \mu \mathrm{m}$ 
internally but have stout external tubes of varying length (Figs 2-3). The girdle elements are finely punctate. In the samples examined the apical axis was $12-33 \mu \mathrm{m}$, the transapical axis $8-18 \mu \mathrm{m}$ and there were $20-25$ areolae in $10 \mu \mathrm{m}$. The material examined was marine neritic phytoplankton from three areas; Bahia San Antonio, Banco Reparo, 20/VII/84, sample No 2(1) where the surface water temperature was $8^{\circ} \mathrm{C}$; Canal Escondido, 22/VIII/84, sample No 9(1), surface temperature $8.5^{\circ} \mathrm{C}$; and Golfo San Matias, Las Grutas, 5/II/85, samples No 47(1), (2), surface temperature $21^{\circ} \mathrm{C}$.

\section{References}

Hasle, G. R. and E. E. Syvertsen. 1980. The diatom genus Cerataulina: morphology and taxonomy. Bacillaria 3: 79113

Hoban, M. A. 1983. Biddulphioid Diatoms. II. The morphology and systematics of the pseudocellate species, Biddulphia biddulphiana (Smith) Boyer, B. alternans (Bailey) Van Heurck, and Trigonium arcticum (Brightwell) Cleve. Bot. Mar. 26: $271-284$

Hustedt, F. 1939. Die Diatomeenflora des Küstengebietes der Nordsee vom Dollart bis zur Elbemündung. I. Abh. Nat. Ver. Bremen 31: 573-676.

\section{Discussion}

Odontella rostrata is correctly placed in the genus Odontella because of the presence of ocellate elevations. This species is morphologically related to the poroid forms of the genus such as Odontella aurita (Lyngbye) Agardh and Odontella litigiosa (Van Heurck) Hoban.

\section{Acknowledgements}

I wish to express my thanks to Dr J. Nelson Navarro for his helpful review of this manuscript.

Ross, R. and P. A. Sims. 1971. Generic limits in Biddulphiaceae as indicated by the scanning electron microscope. In: (V. H. Heywood, ed.) Scanning Electron Microscopy. Academic Press, N. Y., U. S. A. pp. 155-176.

Ross, R., E. J. Cox, N. I. Karayeva, D. G. Mann, T. B. B. Paddock, R. Simonsen and P. A. Sims. 1979. An amended terminology for the siliceous components of the diatom cell. Nova Hedwigia, Beih. 64: 511-533.

Simonsen, R. 1987. Atlas and Catalogue of the Diatom Types of Friederich Hustedt. J. Cramer. Berlin. Stuttgart. Catalogue, Vol. 1. 525 pp., Atlas, Vol. 2. 395 pl. 